\title{
Optimasi Multirespon Wire Electrical Discharge Machining untuk Pengerjaan Punch and Dies Bracket Kapal Alumunium
}

\author{
Fipka Bisono ${ }^{1)^{\star}}$, Dhika Aditya $\mathbf{P .}^{2)}$ \\ ${ }^{1,2)}$ Jurusan Teknik Permesinan Kapal, Politeknik Perkapalan Negeri Surabaya
}

Naskah diterima 13 September 2019; direvisi 22 September 2019; disetujui 28 Oktober 2019 doi: https://doi.org/10.24843/JEM.2019.v12.i02.p11

\begin{abstract}
Abstrak
Wire electrical discharge machining (WEDM) banyak digunakan untuk proses pembuatan punch and dies. Dimana material yang digunakan memiliki tingkat kekerasan yang sangat tinggi. Parameter pemesinan yang kurang tepat dapat menyebabkan hasil pemotongan yang tidak optimal. Penelitian ini dilakukan untuk mengoptimalkan beberapa karakteristik hasil proses pemesinan secara serentak dengan cara mevariasikan variabel-variabel proses pemesinan WEDM. Karakteristik hasil proses yang diteliti antara lain adalah lebar pemotongan, kekasaran permukaan, dan tebal lapisan white layer. Proses pemesinan dilakukan pada material tool steel SKD 11. Arc on time, on time, open voltage dan servo voltage merupakan variabel-variabel proses yang akan divariasikan. Rancangan percobaan dilakukan menggunakan metode Taguchi dengan matriks ortogonal $\mathrm{L}_{18}\left(2^{1} \times 3^{3}\right)$ dengan dua kali replikasi. Sedangkan langkah yang digunakan untuk mengoptimasi karakteristik hasil proses pemesinan yang diteliti secara serentak adalah menggunakan metode grey relational analysis (GRA). Lebar pemotongan, kekasaran permukaan dan tebal lapisan white layer memiliki performance characteristics "smaller-is-better." Hasil dari penelitian menunjukkan nilai variabel-variabel proses pemesinan yang menghasilkan kualitas karakteristik yang paling optimum adalah sebagai berikut: arc on time $(1 \mathrm{~A})$, on time $(4 \mu \mathrm{s})$, open voltage $(70 \mathrm{~V})$, dan servo voltage $(40 \mathrm{~V})$. Dengan persentase kontribusi variabel proses dari yang terbesar berturut-turut adalah on time $(65,09 \%)$, open voltage $(11,35 \%)$, arc on time $(7,71 \%)$, dan servo voltage $(5,61 \%)$.
\end{abstract}

Kata kunci: GRA, kekasaran permukaan, lebar pemotongan, wire-EDM, white layer

\section{Abstract}

Wire electrical discharge machining (WEDM) process is commonly used to make punch and dies. WEDM services are typically used to cut hard metals. Inappropriate machining parameters can cause suboptimal cutting results. This research was conducted to optimize several characteristics of the machining process simultaneously by varying WEDM machining process variables. Performance characteristics of the WEDM process include the kerf, surface roughness and thickness of the white layer. The machining process is carried out on SKD 11 tool steel material. Arc on time, on time, open voltage and servo voltage are process variables that will be varied. The experimental matrix design was carried out using the Taguchi method $L_{18}\left(2^{1} \times 3^{3}\right)$ orthogonal array with two replications. Then to optimize the performance characteristics of the machining process simultaneously is using the Gray Relational Analysis (GRA) method. Performance characteristics of kerf, surface roughness, and thickness of the white layer is "smaller-is-better". The results of the experiment indicate the value of the machining process

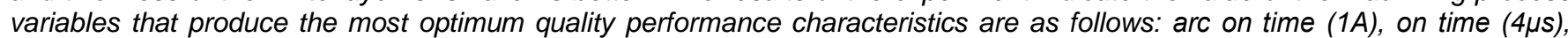
open voltage (70V), and servo voltage (40V). And the percentage of contribution of the process variables from the largest to smallest are as follows: on time (65,09\%), open voltage (11,35\%), arc on time $(7,71 \%)$, and servo voltage $(5,61 \%)$.

Keywords: GRA, surface roughness, kerf, wire-EDM, white layer

\section{Pendahuluan}

Indonesia merupakan salah satu negara kepulauan terbesar di dunia. Banyak sektor yang berpengaruh terhadap kemajuan perekonomian indonesia sebagai negara maritim. Industri perkapalan adalah salah satu sektor yang paling berperan memajukan perekonomian Indonesia. Saat ini industri perkapalan kecil dan menengah mulai beralih dari produksi kapal fiber atau kayu ke kapal aluminium. Karena selain ramah lingkungan kapal ini juga tahan karat dan tidak mudah terbakar. Di industri perkapalan banyak kendala yang dihadapi terkait laju produksi yang sangat rendah. Hal ini disebabkan karena banyaknya komponen-komponen kapal seperti gading dan bracket yang harus diproduksi, sedangkan proses manufaktur yang digunakan tidak mendukung. Penggunaan presstool and dies mampu meningkatkan laju produksi khususnya untuk kapal aluminium.
Proses ini mampu memproses plat dengan cepat dengan hasil yang presisi. Tetapi kualitas hasil produksi tergantung kualitas presstool and dies yang digunakan. Karena presstool and dies menggunakan bahan yang sangat keras maka alat ini hanya mampu dibuat menggunakan proses WEDM.

Wire electrical discharge machining (WEDM) adalah salah satu proses pemesinan non-konvesional yang banyak diaplikasikan di industri aerospace, otomotif, nuklir, medis dan pembuatan die-mould. Proses WEDM memanfaatkan energi termal dari loncatan bunga api akibat perbedaan tegangan antara elektroda dan benda kerja yang bersifat konduktif di dalam suatu media dielektrik. Ilustrasi proses pemotongan WEDM ditunjukkan pada Gambar 1. 


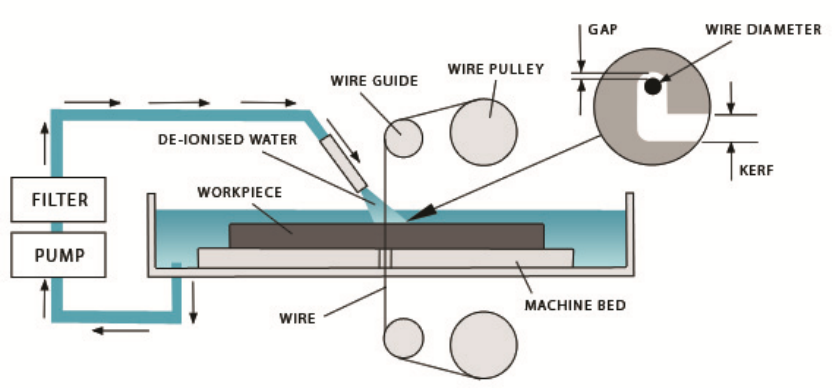

Gambar 1. Proses WEDM

Kinerja dari proses pemesinan WEDM biasanya dievaluasi dari lebar pemotongan, kekasaran permukaan, dan ketebalan lapisan white layer. Lebar pemotongan menentukan tingkat keakurasian dimensi benda kerja yang dihasilkan, kekasaran permukaan merupakan karakteristik kualitas hasil akhir suatu produk. sedangkan ketebalan white layer berpengaruh terhadap sifat-sifat mekanis permukaan benda kerja.

Suatu penelitian mengenai variabel-variabel proses pemesinan WEDM terhadap variabel respon laju pengerjaan bahan dan kekasaran permukaan pada bahan aluminum matrix composites (AMC $413 / B_{4} C$ ) telah dilakukan dengan variabel-variabel proses yang digunakan adalah pulse on time, pulse off time, gap voltage, wire feed dan reinforcement. Hasil penelitian menunjukkan bahwa laju pengerjaan bahan yang paling besar didapatkan dengan kombinasi pulse on time $10 \mu \mathrm{s}$, pulse off time $2 \mu \mathrm{s}$, gap voltage $30 \mathrm{~V}$, wire feed $4 \mathrm{~m} / \mathrm{min}$ dan reinforcement $3 w t \%$. Hasil penelitian juga menunjukkan kekasaran permukaan yang paling rendah didapatkan dengan kombinasi pulse on time $2 \mu \mathrm{s}$, pulse off time $6 \mu \mathrm{s}$, gap voltage $30 \mathrm{~V}$, wire feed 6 $\mathrm{m} / \mathrm{min}$ dan reinforcement 3wt\% (Prakash dkk, 2017).

Penentuan kombinasi variabel-variabel proses agar tercapai respon yang optimum, harus dilakukan dengan menggunakan rancangan percobaan yang tepat. Hal ini bertujuan untuk mengurangi proses trial and error, sehingga waktu dan biaya proses pemesinan dapat diminimumkan. Metode Taguchi adalah salah satu rancangan percobaan yang dapat digunakan dalam penelitian. Tetapi metode Taguchi tidak bisa digunakan untuk melakukan optimasi multirespon secara serentak. Untuk optimasi multirespon secara serentak dapat digunakan gabungan metode Taguchi dengan grey relational analysis.

Berdasarkan latar belakang tersebut diatas, penelitian tentang optimasi pengaturan variabelvariabel proses pemesinan WEDM perlu dilakukan untuk menghasilkan respon lebar pemotongan, kekasaran permukaan dan ketebalan white layer yang minimum. Rancangan percobaan pada penelitian menggunakan matriks ortogonal $L_{18}$, sedangkan metode optimasi menggunakan kombinasi metode Taguchi-grey.

\section{Metode penelitian}

\subsection{Material $\mathrm{Uji}$}

Material yang digunakan pada penelitian ini adalah tool steel SKD 11. Baja ini memiliki kekerasan yang cukup tinggi, karena sifatnya yang keras, material tersebut sering digunakan untuk pembuatan punch and dies. Jenis kawat elektroda yang digunakan adalah zinc coated brass wire dengan diameter 0,3 $\mathrm{mm}$. Sedangkan dielectric fluid yang digunakan adalah aquadestilata. Percobaan pemotongan dilakukan sepanjang $20 \mathrm{~mm}$ sebanyak 18 kali dengan dua kali proses replikasi. llustrasi proses pemotongan pada spesimen uji dapat dilihat pada Gambar 2.

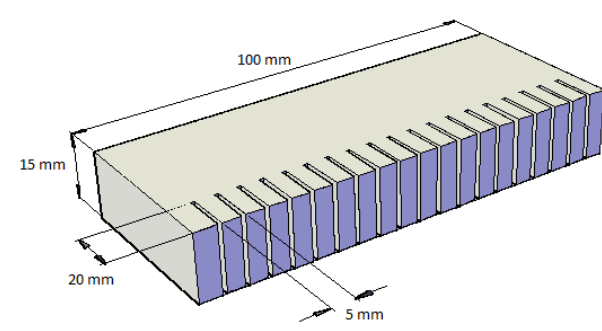

Gambar 2. Ilustrasi proses pemotongan

\subsection{Peralatan Penelitian.}

Mesin yang digunakan pada penelitian ini adalah WEDM tipe CHMER GF32. Tingkat kekasaran permukaan diukur menggunakan Mitutoyo surftest SJ310 , dengan kecermatan $0,01 \mu \mathrm{m}$. Pengambilan data kekasaran permukaan dilakukan pada permukaan benda kerja hasil proses pemotongan sebanyak tiga kali pengulangan kemudian hasilnya di rata-rata. Gambar 3. Menunjukkan ilustrasi bagian permukaan benda kerja yang akan diukur kekasarannya.

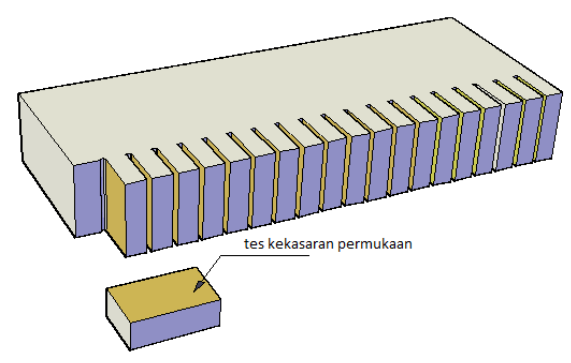

Gambar 3. Tes kekasaran permukaan

Lebar pemotongan diukur dengan menggunakan measurescope dengan kecermatan 0,001 mm. Pengukuran lebar pemotongan juga dilakukan sebanyak tiga kali kemudian hasilnya dirata-rata. llustrasi pengukuran lebar pemotongan ditunjukkan pada Gambar 4. 


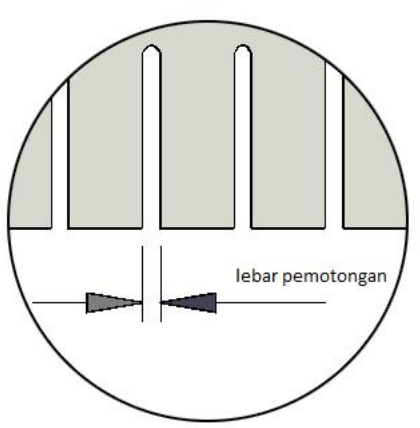

Gambar 4. Lebar pemotongan

Sedangkan untuk tebal lapisan white layer dapat dilihat dan diukur menggunakan Scanning Electron Microscope (SEM). Gambar 5. menunjukkan ilustrasi bagian white layer yang yang akan di lihat menggunakan SEM. Tebal lapisan white layer dihitung dengan cara membagi luasan bagian white layer yang diteliti dibagi dengan panjangnya.

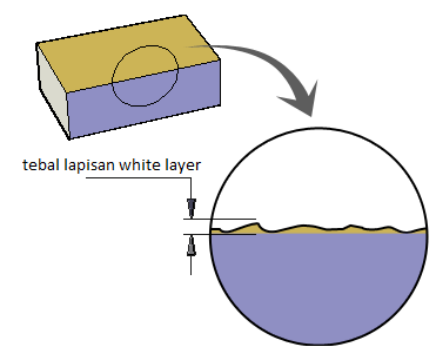

Gambar 5. Tebal lapisan white layer

\subsection{Rancangan Percobaan}

Variabel-variabel proses yang divariasikan pada penelitian ini adalah arc on time, on time, open voltage dan servo voltage. Level dan nilai dari masing-masing variabel proses ditunjukkan pada Tabel 1. Rancangan percobaan menggunakan matriks ortogonal $\mathrm{L}_{18}\left(2^{1} \times 3^{3}\right)$ ditunjukkan pada Tabel 2, dengan dua kali replikasi. Untuk menganalisa dan mengoptimasi data hasil percobaan digunakan kombinasi metode Taguchi dengan metode GRA

Tabel 1. Variabel-variabel proses

\begin{tabular}{|c|c|c|c|c|c|c|}
\hline \multirow{2}{*}{ No. } & \multirow{2}{*}{ Variabel } & \multirow{2}{*}{ Simbol } & \multicolumn{3}{|c|}{ Level } & \multirow[t]{2}{*}{ Unit } \\
\hline & & & 1 & 2 & 3 & \\
\hline 1 & $\begin{array}{c}\text { Arc on } \\
\text { time }\end{array}$ & AN & 1 & 2 & - & A \\
\hline 2 & On time & ON & 4 & 6 & 8 & $\mu \mathrm{s}$ \\
\hline 3 & $\begin{array}{c}\text { Open } \\
\text { voltage }\end{array}$ & OV & 70 & 90 & 110 & V \\
\hline 4 & $\begin{array}{c}\text { Servo } \\
\text { voltage }\end{array}$ & SV & 40 & 50 & 60 & V \\
\hline
\end{tabular}

Tabel 2. Matriks Orthogonal $\mathrm{L}_{18}\left(2^{1} \times 3^{3}\right)$

\begin{tabular}{ccccc}
\hline \multirow{2}{*}{ Komb. } & \multicolumn{4}{c}{ Variabel proses } \\
\cline { 2 - 5 } & AN & ON & OV & SV \\
\hline 1 & 1 & 4 & 70 & 40 \\
\hline 2 & 1 & 4 & 90 & 50 \\
\hline 3 & 1 & 4 & 110 & 60 \\
\hline 4 & 1 & 6 & 70 & 40 \\
\hline 5 & 1 & 6 & 90 & 50 \\
\hline 6 & 1 & 6 & 110 & 60 \\
\hline 7 & 1 & 8 & 70 & 50 \\
\hline 8 & 1 & 8 & 90 & 60 \\
\hline 9 & 1 & 8 & 110 & 40 \\
\hline 10 & 2 & 4 & 70 & 60 \\
\hline 11 & 2 & 4 & 90 & 40 \\
\hline 12 & 2 & 4 & 110 & 50 \\
\hline 13 & 2 & 6 & 70 & 50 \\
\hline 14 & 2 & 6 & 90 & 60 \\
\hline 15 & 2 & 6 & 110 & 40 \\
\hline 16 & 2 & 8 & 70 & 60 \\
\hline 17 & 2 & 8 & 90 & 40 \\
\hline 18 & 2 & 8 & 110 & 50 \\
\hline
\end{tabular}

\subsection{Metode Optimasi}

Pada penelitian ini optimasi dilakukan dengan menggunakan metode GRA dengan menghitung rasio $\mathrm{S} / \mathrm{N}$ pada setiap respon yang dioptimasi. Pendekatan rasio $\mathrm{S} / \mathrm{N}$ dilakukan untuk meminimalisir noise terhadap variasi yang timbul. Penentuan nilai rasio $\mathrm{S} / \mathrm{N}$ harus disesuaikan dengan characteristic performance pada tiap-tiap respon. Respon kekasaran permukaan, lebar pemotongan dan tebal lapisan white layer pada penelitian ini memiliki characteristic performance "smaller-is-better." Dengan demikian nilai rasio S/N dapat dihitung dengan menggunakan persamaan sebagai berikut (Lin dkk., 2002):

$$
\mathrm{S} / \mathrm{N}=-10 \log \left[\sum_{\mathrm{i}=1}^{\mathrm{n}} \frac{\mathrm{y}_{\mathrm{i}}{ }^{2}}{\mathrm{n}}\right]
$$

Dimana, $n$ adalah banyaknya replikasi, dan $y_{i}$ adalah nilai respon. Nilai rasio $S / N$ yang besar menunjukkan characteristic performance yang lebih baik.

Nilai rasio $\mathrm{S} / \mathrm{N}$ kemudian dinormalisasi menjadi nilai yang besarnya antara 0 sampai 1 . Normalisasi dihitung dengan menggunakan persamaan sebagai berikut (Lin dkk., 2002):

$$
X_{i}^{*}(k)=\frac{X_{i}(k)-\min _{\forall k} X_{i}(k)}{\max _{\forall k} X_{i}(k)-\min _{\forall k} X_{i}(k)}
$$

Dimana, $\min X_{i}(k)$ adalah nilai terkecil dari $X_{i}(k)$ untuk respon ke- $k$, dan $\max X_{i}(k)$ adalah nilai terbesar dari $X_{i}(k)$ untuk respon ke- $k$. Nilai $X_{i}^{*}(k)$ pada tiap-tiap respon kemudian diubah menjadi nilai grey relational coefficient (GRC). Untuk menghitung nilai GRC $\left(\xi_{i}\right)$ digunakan persamaan (Lin dkk., 2002):

$$
\xi_{i}(k)=\frac{\Delta_{\min }+\zeta \Delta_{\max }}{\Delta_{0, \mathrm{i}}(\mathrm{k})+\zeta \Delta_{\max }}
$$

Dimana, $\Delta_{0, i}(k)=\left|X_{i}(k)-X_{i}^{*}(k)\right|$ adalah selisih nilai absolut antara $x_{0}(k)$ dan $x_{i}(k), \Delta_{\text {min }}$ merupakan nilai terkecil dari $\Delta_{0, i}, \Delta_{\max }$ merupakan nilai terbesar 
dari $\Delta_{0, i}$, dan $\zeta$ adalah distinguishing coefficient yang pada penelitian ini nilainya ditentukan sebesar 0,5.

Nilai GRC pada tiap-tiap respon kemudian di ratarata untuk mendapatkan nilai GRG. Berdasarkan nilai
GRG ini kemudian dianalisa untuk menentukan kombinasi dari level-level dan variabel-variabel mana yang menghasilkan nilai optimum dari semua respon

Tabel 3. Data hasil percobaan

\begin{tabular}{|c|c|c|c|c|c|c|c|c|c|c|}
\hline \multirow[t]{2}{*}{ Komb. } & \multicolumn{4}{|c|}{ Variabel proses } & \multicolumn{2}{|c|}{$\begin{array}{l}\text { Lebar pemotongan } \\
\qquad(\mathrm{LP})(\mathrm{mm})\end{array}$} & \multicolumn{2}{|c|}{$\begin{array}{l}\text { Kekasaran } \\
\text { permukaan } \\
(\mathrm{KP})(\mu \mathrm{m})\end{array}$} & \multicolumn{2}{|c|}{$\begin{array}{c}\text { Tebal lapisan white layer } \\
\text { (TW) }(\mu \mathrm{m})\end{array}$} \\
\hline & AN & ON & OV & SV & $\mathrm{R} 1$ & $\mathrm{R} 2$ & $\mathrm{R} 1$ & $\mathrm{R} 2$ & $\mathrm{R} 1$ & $\mathrm{R} 2$ \\
\hline 1 & 1 & 4 & 70 & 40 & 0.359 & 0.330 & 1.39 & 1.42 & 5.801 & 5.131 \\
\hline 2 & 1 & 4 & 90 & 50 & 0.332 & 0.341 & 1.69 & 1.95 & 5.998 & 7.298 \\
\hline 3 & 1 & 4 & 110 & 60 & 0.337 & 0.382 & 1.47 & 1.38 & 6.923 & 5.415 \\
\hline 4 & 1 & 6 & 70 & 40 & 0.349 & 0.334 & 1.76 & 1.97 & 7.165 & 6.166 \\
\hline 5 & 1 & 6 & 90 & 50 & 0.346 & 0.376 & 1.94 & 1.85 & 7.172 & 7.541 \\
\hline 6 & 1 & 6 & 110 & 60 & 0.383 & 0.367 & 1.85 & 1.92 & 9.890 & 7.002 \\
\hline 7 & 1 & 8 & 70 & 50 & 0.362 & 0.351 & 2.17 & 2.12 & 6.480 & 6.962 \\
\hline 8 & 1 & 8 & 90 & 60 & 0.374 & 0.346 & 2.31 & 2.15 & 7.121 & 8.665 \\
\hline 9 & 1 & 8 & 110 & 40 & 0.356 & 0.355 & 2.40 & 2.41 & 8.935 & 8.354 \\
\hline 10 & 2 & 4 & 70 & 60 & 0.378 & 0.380 & 1.21 & 1.43 & 7.392 & 5.618 \\
\hline 11 & 2 & 4 & 90 & 40 & 0.356 & 0.351 & 1.75 & 1.63 & 6.778 & 5.285 \\
\hline 12 & 2 & 4 & 110 & 50 & 0.334 & 0.347 & 1.93 & 2.25 & 8.514 & 7.345 \\
\hline 13 & 2 & 6 & 70 & 50 & 0.352 & 0.359 & 2.31 & 1.96 & 5.213 & 6.516 \\
\hline 14 & 2 & 6 & 90 & 60 & 0.391 & 0.374 & 1.85 & 1.87 & 9.412 & 8.906 \\
\hline 15 & 2 & 6 & 110 & 40 & 0.364 & 0.341 & 2.24 & 2.26 & 10.102 & 7.650 \\
\hline 16 & 2 & 8 & 70 & 60 & 0.383 & 0.380 & 2.23 & 2.31 & 10.324 & 8.753 \\
\hline 17 & 2 & 8 & 90 & 40 & 0.317 & 0.376 & 2.77 & 2.60 & 11.714 & 8.331 \\
\hline 18 & 2 & 8 & 110 & 50 & 0.358 & 0.361 & 1.94 & 2.38 & 11.221 & 9.862 \\
\hline
\end{tabular}

yang diteliti. Kemudian langkah berikutnya melakukan prediksi terhadap nilai rata-rata GRG pada kondisi optimum. Prediksi nilai rata-rata GRG $(\hat{\gamma})$ dapat dihitung dengan menggunakan persamaan sebagai berikut (Lin dkk., 2002):

$$
\hat{\gamma}=\gamma_{m}+\sum_{i=1}^{q}\left(\bar{\gamma}_{i}-\gamma_{m}\right)
$$

Dimana, $\gamma_{m}$ adalah nilai rata-rata total GRG, $\bar{\gamma}_{i}$ adalah nilai rata-rata GRG pada level optimum, dan $q$ adalah jumlah variabel-variabel proses yang berpengaruh secara signifikan terhadap respon GRG.

Percobaan konfirmasi perlu dilakukan, untuk memvalidasi bahwa kombinasi level-level dan variabelvariabel proses yang menghasilkan respon optimum adalah benar. Kombinasi tersebut dapat dinyatakan valid jika nilai rata-rata GRG pada percobaan konfirmasi berada di dalam atau bersinggungan dengan interval nilai rata-rata GRG prediksi.

\section{Hasil dan Pembahasan}

\subsection{Hasil percobaan}

Nilai lebar pemotongan, kekasaran permukaan, dan tebal lapisan white layer dari hasil percobaan pada replikasi pertama (R1) dan replikasi kedua (R2) ditunjukkan pada Tabel 3. Dari data hasil percobaan kemudian dihitung nilai rasio $\mathrm{S} / \mathrm{N}$ pada tiap-tiap responnya. Nilai rasio S/N ditunjukkan pada Tabel 4.
Tabel 4.Nilai rasio $\mathrm{S} / \mathrm{N}$

\begin{tabular}{cccc}
\hline \multirow{2}{*}{ Komb. } & \multicolumn{3}{c}{ Rasio S/N } \\
\cline { 2 - 4 } & LP & KP & TW \\
\hline 1 & 9.249 & -2.954 & -14.770 \\
\hline 2 & 9.460 & -5.224 & -16.495 \\
\hline 3 & 8.869 & -3.081 & -15.869 \\
\hline 4 & 9.330 & -5.427 & -16.501 \\
\hline 5 & 8.842 & -5.555 & -17.336 \\
\hline 6 & 8.517 & -5.508 & -18.658 \\
\hline 7 & 8.958 & -6.629 & -16.554 \\
\hline 8 & 8.867 & -6.972 & -17.986 \\
\hline 9 & 8.983 & -7.622 & -18.740 \\
\hline 10 & 8.427 & -2.442 & -16.345 \\
\hline 11 & 9.032 & -4.563 & -15.675 \\
\hline 12 & 9.356 & -6.428 & -18.008 \\
\hline 13 & 8.983 & -6.617 & -15.418 \\
\hline 14 & 8.345 & -5.390 & -19.240 \\
\hline 15 & 9.052 & -7.044 & -19.046 \\
\hline 16 & 8.370 & -7.122 & -19.619 \\
\hline 17 & 9.175 & -8.583 & -20.141 \\
\hline 18 & 8.886 & -6.734 & -20.476 \\
\hline & & & \\
\hline
\end{tabular}

\subsection{Normalisasi Rasio $\mathrm{S} / \mathrm{N}$.}

Nilai rasio $\mathrm{S} / \mathrm{N}$ kemudian dinormalisasi berdasarkan persamaan 2. Hasil dari normalisasi rasio $\mathrm{S} / \mathrm{N}$ ditunjukkan pada Tabel 5. 
Tabel 5.Nilai normalisasi rasio $\mathrm{S} / \mathrm{N}$

\begin{tabular}{cccc}
\hline \multirow{2}{*}{ Komb. } & \multicolumn{3}{c}{ Normalisai S/N $\left(\mathrm{X}_{\mathrm{i}}^{*}\right)$} \\
\cline { 2 - 4 } & $\mathrm{LP}$ & $\mathrm{KP}$ & $\mathrm{TW}$ \\
\hline 1 & 0.8106 & 0.9166 & 1.0000 \\
\hline 2 & 1.0000 & 0.5470 & 0.6976 \\
\hline 3 & 0.4701 & 0.8959 & 0.8074 \\
\hline 4 & 0.8838 & 0.5139 & 0.6966 \\
\hline 5 & 0.4461 & 0.4931 & 0.5502 \\
\hline 6 & 0.1545 & 0.5008 & 0.3186 \\
\hline 7 & 0.5497 & 0.3182 & 0.6873 \\
\hline 8 & 0.4686 & 0.2624 & 0.4363 \\
\hline 9 & 0.5725 & 0.1565 & 0.3043 \\
\hline 10 & 0.0736 & 1.0000 & 0.7239 \\
\hline 11 & 0.6163 & 0.6545 & 0.8414 \\
\hline 12 & 0.9072 & 0.3509 & 0.4324 \\
\hline 13 & 0.5722 & 0.3201 & 0.8864 \\
\hline 14 & 0.0000 & 0.5199 & 0.2166 \\
\hline 15 & 0.6345 & 0.2507 & 0.2505 \\
\hline 16 & 0.0223 & 0.2379 & 0.1502 \\
\hline 17 & 0.7443 & 0.0000 & 0.0586 \\
\hline 18 & 0.4853 & 0.3011 & 0.0000 \\
\hline
\end{tabular}

\subsection{Deviation Squence}

Deviation squence $\left(\Delta_{0, i}\right)$ dihitung dengan persamaan 3 , hasil dari perhitungan deviation squence untuk semua respon pada tiap-tiap kombinasi ditunjukkan pada Tabel 6.

Tabel 6. Nilai Deviation squence

\begin{tabular}{cccc}
\hline \multirow{2}{*}{ Komb. } & \multicolumn{3}{c}{ Deviation squence $\left(\Delta_{\mathbf{0}, i}\right)$} \\
\cline { 2 - 4 } & LP & KP & TW \\
\hline 1 & 0.1894 & 0.0834 & 0.0000 \\
\hline 2 & 0.0000 & 0.4530 & 0.3024 \\
\hline 3 & 0.5299 & 0.1041 & 0.1926 \\
\hline 4 & 0.1162 & 0.4861 & 0.3034 \\
\hline 5 & 0.5539 & 0.5069 & 0.4498 \\
\hline 6 & 0.8455 & 0.4992 & 0.6814 \\
\hline 7 & 0.4503 & 0.6818 & 0.3127 \\
\hline 8 & 0.5314 & 0.7376 & 0.5637 \\
\hline 9 & 0.4275 & 0.8435 & 0.6957 \\
\hline 10 & 0.9264 & 0.0000 & 0.2761 \\
\hline 11 & 0.3837 & 0.3455 & 0.1586 \\
\hline 12 & 0.0928 & 0.6491 & 0.5676 \\
\hline 13 & 0.4278 & 0.6799 & 0.1136 \\
\hline 14 & 1.0000 & 0.4801 & 0.7834 \\
\hline 15 & 0.3655 & 0.7493 & 0.7495 \\
\hline 16 & 0.9777 & 0.7621 & 0.8498 \\
\hline 17 & 0.2557 & 1.0000 & 0.9414 \\
\hline 18 & 0.5147 & 0.6989 & 1.0000 \\
\hline
\end{tabular}

\subsection{GRC dan GRG}

Berdasarkan persamaan 3 nilai GRC dihitung untuk kemudian hasilnya pada tiap-tiap respon diratarata menjadi nilai GRG. Nilai GRG ini yang nantinya mewakili nilai semua respon secara serentak untuk dioptimasi. Nilai GRC dan GRG hasil perhitungan di tunjukkan pada Tabel 7.
Tabel 7. Nilai GRC dan GRG

\begin{tabular}{ccccc}
\hline \multirow{2}{*}{ Komb. } & \multicolumn{3}{c}{ GRC } & \multirow{2}{*}{ GRG } \\
\cline { 2 - 4 } & LP & KP & TW & \\
\hline 1 & 0.7253 & 0.8570 & 1.0000 & 0.8608 \\
\hline 2 & 1.0000 & 0.5247 & 0.6232 & 0.7159 \\
\hline 3 & 0.4855 & 0.8277 & 0.7219 & 0.6784 \\
\hline 4 & 0.8115 & 0.5070 & 0.6224 & 0.6470 \\
\hline 5 & 0.4744 & 0.4966 & 0.5265 & 0.4992 \\
\hline 6 & 0.3716 & 0.5004 & 0.4232 & 0.4317 \\
\hline 7 & 0.5262 & 0.4231 & 0.6152 & 0.5215 \\
\hline 8 & 0.4848 & 0.4040 & 0.4701 & 0.4530 \\
\hline 9 & 0.5391 & 0.3722 & 0.4182 & 0.4431 \\
\hline 10 & 0.3505 & 1.0000 & 0.6443 & 0.6649 \\
\hline 11 & 0.5658 & 0.5914 & 0.7592 & 0.6388 \\
\hline 12 & 0.8434 & 0.4351 & 0.4684 & 0.5823 \\
\hline 13 & 0.5389 & 0.4238 & 0.8149 & 0.5925 \\
\hline 14 & 0.3333 & 0.5101 & 0.3896 & 0.4110 \\
\hline 15 & 0.5777 & 0.4002 & 0.4002 & 0.4594 \\
\hline 16 & 0.3384 & 0.3962 & 0.3704 & 0.3683 \\
\hline 17 & 0.6616 & 0.3333 & 0.3469 & 0.4473 \\
\hline 18 & 0.4927 & 0.4171 & 0.3333 & 0.4144 \\
\hline
\end{tabular}

\subsection{Kombinasi respon optimum.}

Dilihat pada Tabel 8 menunjukkan bahwa nilai $p$ value seluruh variabel proses lebih kecil dari alpha $5 \%$. Dengan demikian dapat disimpulkan bahwa berdasarkan statistik variabel-variabel proses pada penelitian ini yang meliputi: arc on time, on time, open voltage dan servo voltage menunjukkan pengaruh yang signifikan terhadap respon lebar pemotongan, kekasaran permukaan, dan tebal lapisan white layer yang diteliti secara serentak.

Tabel 8. Nilai ANAVA GRG

\begin{tabular}{ccccccr}
\hline Source & df & SS & MS & $F$ & $\begin{array}{c}P \\
\text { value }\end{array}$ & Kontribusi \\
\hline AN & 1 & 0.02506 & 0.025060 & 13.81 & 0.004 & $7.71 \%$ \\
\hline ON & 2 & 0.19979 & 0.099896 & 55.04 & 0.000 & $65.09 \%$ \\
\hline OV & 2 & 0.03784 & 0.018921 & 10.42 & 0.004 & $11.35 \%$ \\
\hline SV & 2 & 0.02053 & 0.010266 & 5.66 & 0.023 & $5.61 \%$ \\
\hline Error & 10 & 0.01815 & 0.001815 & & & $10.24 \%$ \\
\hline Total & 17 & 0.30137 & & & & $100 \%$ \\
\hline
\end{tabular}

Kombinasi level dan variabel proses yang menghasilkan respon optimum dapat ditentukan dari nilai rata-rata GRG yang paling besar. Berdasarkan grafik plot nilai rata-rata GRG seperti ditunjukkan pada Gambar 6, didapatkan nilai kombinasi yang menghasilkan respon optimum adalah variabel proses

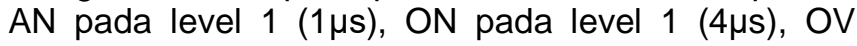
pada level 1 (70V) dan SV pada level 1 (40V). 
Fipka Bisono \& Aditya /Jurnal Energi dan Manufaktur Vol. 12 No. 2, Oktober 2019 (107-113)

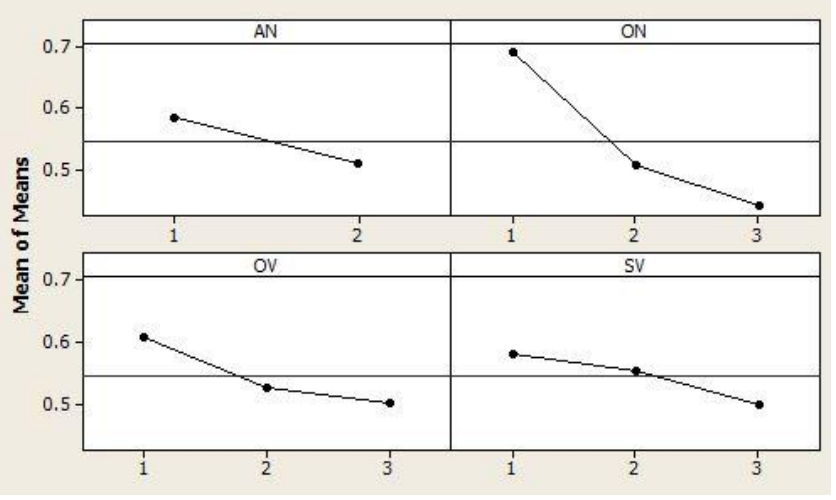

3.6. Perbandingan kondisi awal dengan optimum.

Perbandingan nilai respon hasil proses pemesinan WEDM antara kondisi awal dengan kondisi optimum ditunjukkan pada Tabel 9. Berdasarkan Tabel 9, nilai GRG pada kondisi awal adalah sebesar 0,5910 dan nilai GRG pada kondisi optimum adalah sebesar 0,80381. Dengan demikian nilai GRG mengalami peningkatan sebesar $41,81 \%$.

Tabel 9. Percobaan konfirmasi

\begin{tabular}{|c|c|c|c|}
\hline \multirow{3}{*}{ Respon } & \multirow{2}{*}{ Kombinasi awal } & \multicolumn{2}{|c|}{ Kombinasi optimum } \\
\hline & & Prediksi & Konfirmasi \\
\hline & $\mathrm{AN}_{1} \mathrm{ON}_{2} \mathrm{OV}_{2} \mathrm{SV}_{2}$ & $\mathrm{AN}_{1} \mathrm{ON}_{1} \mathrm{OV}_{1} \mathrm{SV}_{1}$ & $\mathrm{AN}_{1} \mathrm{ON}_{1} \mathrm{OV}_{1} \mathrm{SV}_{1}$ \\
\hline Lebar pemotongan (LP) & 0.349 & 0.345 & 0.347 \\
\hline Kekasaran permukaan (KP) & 1.91 & 1.41 & 1.42 \\
\hline Tebal lapisan white layer (TW) & 6.947 & 5.46 & 5.322 \\
\hline Rasio S/N (LP) & 9.152 & 9.249 & 9.202 \\
\hline Rasio S/N (KP) & -5.636 & -2.954 & -3.067 \\
\hline Rasio S/N (TW) & -16.848 & -14.770 & -14.524 \\
\hline GRG & 0.5910 & $0.8272 \pm 0.04473$ & 0.8381 \\
\hline Peningkatan GRG & & $41.81 \%$ & \\
\hline Peningkatan rasio S/N (LP) & & $0.54 \%$ & \\
\hline Peningkatan rasio S/N (KP) & & $36 \%$ & \\
\hline Peningkatan rasio S/N (TW) & & $13.7 \%$ & \\
\hline
\end{tabular}

Hasil scaning electron microscope (SEM) yang menunjukkan perbandingan tebal lapisan white layer antara kombinasi awal dengan optimum ditunjukkan pada Gambar 7.

Characteristic performance "smaller-isbetter" dari respon lebar pemotongan, kekasaran permukaan, dan tebal lapisan white layer telah terpenuhi. Hal tersebut dibuktikan dengan meningkatnya nilai rasio $\mathrm{S} / \mathrm{N}$ dari tiaptiap respon.

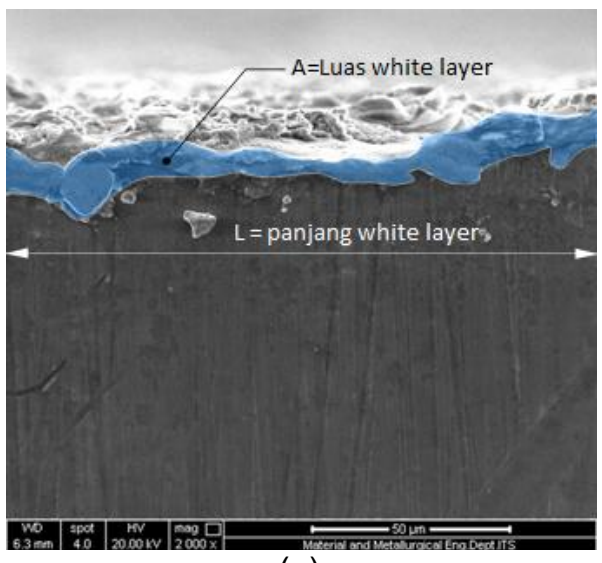

(a)

Gambar 6. Plot nilai GRG

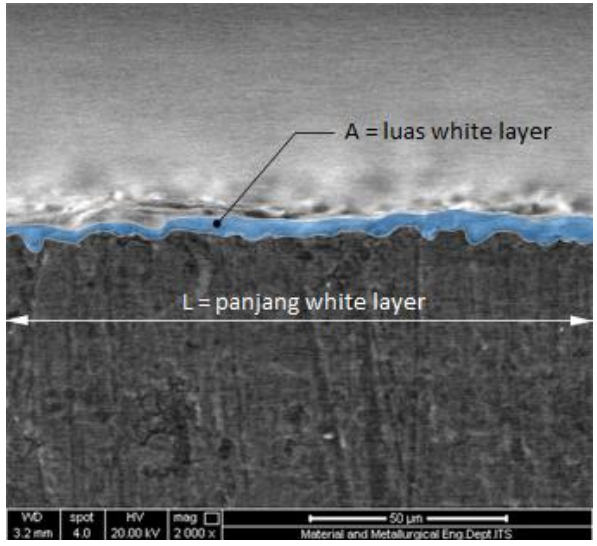

(b)

Gambar 7. Tebal lapisan white layer kombinasi awal (a) vs kombinasi optimum (b)

\section{Simpulan}

Hasil penelitian menunjukkan dengan pengaturan nilai variabel proses arc on time pada $1 \mu \mathrm{s}$, on time pada $4 \mu \mathrm{s}$, open voltage pada $70 \mathrm{~V}$ dan servo voltage pada $40 \mathrm{~V}$ dapat menghasilkan nilai lebar pemotongan, kekasaran permukaan, dan tebal lapisan white layer paling optimum secara serentak.

Sedangkan kontribusi dari masing-masing variabel proses terhadap total variansi respon lebar pemotongan, kekasaran permukaan, dan tebal lapisan white layer yang diamati secara serentak berturut-turut adalah on time sebesar $65,09 \%$, open voltage sebesar $11,35 \%$, arc on 
time sebesar $7,71 \%$ dan servo voltage sebesar $5,61 \%$.

\section{Ucapan Terima kasih}

Ucapan terima kasih kepada Direktorat Riset dan Pengabdian Masyarakat (DRPM) Kemenristek DIKTI yang telah mendanai penelitian ini melalui skema Penelitian Dosen Pemula (PDP) tahun 2019.

\section{Daftar Pustaka}

[1] Udaya Prakash, J., Jebarose Juliyana, S., Karthik S., \& Moorthy, T. V.(2017), "Optimization Of Wire Edm Process Parameters For Machining Of Amcs (413/B4c) Using Taguchi Technique," International Journal of Mechanical and Production Engineering Research and Development (IJMPERD), Vol. 7, pp. 2249-8001.

[2] Kumara, K., Ravikumar R. (2014), "Modeling and Optimization of Wire EDM Process," International Journal of Mechanical \& Mechatronics Engineering, Vol. 14, No. 05

[3] Pujari, S. R., Koona, R. \& Beela, S. (2014), "Experimental Investigation and Optimization of Wire EDM Parameters for Surface Roughness, MRR and White Layer in Machining of Aluminium Alloy," International Conference on Advances in Manufacturing and Materials Engineering, Vol. 5, pp. 2197-2206.

[4] Ghodsiyeh, D., Golshan, A., \& Isman, S. (2014), "Multi-objective process optimization of wire electrical discharge machining based on response surface methodology," Journal of the Brazilian Society of Mechanical Sciences and Engineering, Vol. 36, pp. 301-313.

[5] Groover, M. P. (2002), Fundamentals of Modern Manufacturing, $2^{\text {nd }}$ edition, John Wiley and Sons, Inc., New York.

[6] Lin, J. L. dan Lin, C. L. (2002), "The Use of Orthogonal Array with Grey Relational Analysis to Optimize the Electrical Discharge Machining Process Performance with Multiple Characteristics," International Journal of Machine Tools and Manufacture, Vol. 42, hal. 237-244.

[7] Ghodsiyeh, D., Golshan, A., Shirvanehdeh, J. A. (2013), "Review on Current Research Trends in Wire Electrical Discharge Machining (WEDM)," Indian Journal of Science and Technology, Vol. 6, hal. 4128-4120.

[8] Rochim, T. (2001), Proses Pemesinan, Institut Teknologi Bandung, Bandung.
[9] Soejanto, I. (2009), Desain Eksperimen dengan Metode Taguchi, Graha IImu, Yogyakarta. 